bp Antoni Długosz

\title{
Homilia do dzieci - spojrzenie praktyka
}

Ewangelicki teolog Karl Barth przypomina, że prawdziwy kaznodzieja w jednej ręce powinien trzymać Pismo Święte, a w drugiej gazetę. To prawda, ponieważ Bóg cały czas działa w historii ludzkości i komunikuje się z nami przez rozgrywające się wokół nas wydarzenia. Kaznodzieja ma obowiązek być uważnym obserwatorem, który śledzi rzeczywistość i wyciąga wnioski. Często zapominamy o ograniczonej ludzkiej percepcji, o tym, że warunki w Kościele nie są tak komfortowe, jak w teatrze czy w kinie. W Kościele niekiedy brakuje wygodnych miejsc do siedzenia i trudno się skupić.

Powyższe uwagi należy uwzględnić w przekazie homiletycznym do dzieci, zwracając szczególną uwagę na język homilii, doświadczenie egzystencjalne, interpretację biblijną oraz wykorzystanie pomocy audiowizualnych.

1 Biskup pomocniczy diecezji częstochowskiej, duszpasterz, katechetyk, praktyk, teoretyk, publicysta. Buduje dobry świat dla dzieci. Jako „rozśpiewany biskup” nagrał kilka płyt z piosenkami dla dzieci, pomagając w radosnym przeżywaniu chrześcijaństwa. Spotyka się z dziećmi, młodzieżą, niepełnosprawnymi, uzależnionymi, głuchoniemymi, psychicznie chorymi. Działalność tę rozszerzył udziałem w programie telewizyjnym „Ziarno” oraz w „Kropelce radości” w telewizji Trwam (antonidlugosz@episkopat.pl). 


\section{Werbalny kontakt z dzieckiem}

Rozwój zmysłów u dziecka przebiega, poczynając od zmysłu wzroku, poprzez dotyk, powonienie, zmysł słuchu i mowy. Najsilniejszymi bodźcami w pierwszych latach życia są doświadczenia widzenia oraz dźwięku. Wszystkie zmysły składają się na możliwość kontaktowania się z otaczającym światem. Język dziecka można podzielić na język obrazów, dźwięków, dotyku, powonienia i smaku. Spotykając się z dzieckiem, najpierw trzeba wytworzyć atmosferę bezpieczeństwa i przyjaźni, by zaakceptowało osobę, która będzie się z nim kontaktowała. Nie można narzucać się dziecku - ono samo winno oswoić się z nową osobą i przyjać ją do grona swoich przyjaciół. Kontakt z dzieckiem można nawiązać przez jego rodziców i opiekunów, z którymi jest ono zżyte. Wystarczy przywitać się z rodzicami, rozmawiać z nimi, pozwalając dziecku na oswojenie się. Kiedy dziecko nabierze przekonania, że rodzice akceptują nową osobę, darzą ją życzliwością i sympatią - ono także włączy ją do grona swoich przyjaciół. Można też nawiązać przyjaźń z dzieckiem przez jego rówieśników, którzy znają tego człowieka i darzą go sympatią. Dziecko nabiera przekonania, że można zaufać mu, gdy widzi swoich rówieśników, którzy radośnie witają się z obcym człowiekiem, rozmawiają z nim i uczestniczą w jego zajęciach.

W kontaktach z dziećmi należy zwracać uwagę na barwę głosu oraz jego intensywność. Dzieci są bardzo wrażliwe na intonację i nie można straszyć ich krzykiem lub tonami powodującymi niepokój, a nawet lęki. Przy takiej atmosferze dziecko zamyka się na odbiór przekazu słownego i popada w depresję. 


\section{Wierność dziecku w posłudze homiletycznej}

W przypadku dzieci trzeba im ukazywać pewne epizody z ich życia, by zostały poruszone tymi doświadczeniami i wzięły je za swoje. Chodzi o ukazanie takiej sytuacji, z którą utożsami się dziecko. Dlatego najtrudniejszą sprawą warsztatową w przygotowaniu homilii dla dzieci jest trafne wybranie sytuacji życiowej słuchających nas dzieci. Potrzebujemy do tego poznania świata dziecka, jego przeżyć, jego patrzenia na rzeczywistość. Jeżeli zainteresujemy choćby jedno dziecko prezentowanym materiałem z życia - poprawnie wybraliśmy materiał egzystencjalny dla dziecka, a tym samym dochowujemy wierności człowiekowi. Nieodłącznym elementem wierności dziecku będzie posługiwanie się językiem zrozumiałym dla odbiorcy, językiem komunikatywnym, w którym wystrzegać się będziemy abstrakcyjnych terminów oraz znaków wziętych z filozoficznej terminologii. Budowa zdań powinna być prosta. Należy przestrzegać logiczności wynikania. Do dzieci zwracamy się, korzystając z podobnych słów, jakie stosujemy w komunikacji z dorosłymi.

W kontaktach z dziećmi ważne są metody wykorzystywane podczas homilii. Na pierwszym miejscu wypada wymienić najbardziej aktywny sposób oddziaływania na uczestników homiliijakim jest metoda dialogu. Stosując ją, powinniśmy zwrócić uwagę na poprawność budowy pytań oraz ich jednorodność. Dochowujemy wierności człowiekowi, gdy wykorzystujemy pomoce będące nośnikami przekazywanych treści.

\section{Rola języka w przekazie Bożego słowa}

Nośnikiem Bożego pouczenia jest mowa, ludzki język, którego jakość odgrywa wyjątkową rolę w profetycznej misji. Głoszący 
słowo Boże winien posługiwać się tzw. językiem „katechetycznym", który charakteryzuje się jasnością, logicznością wynikania oraz zrozumiałością przez odbiorców. Głoszący winien korzystać z terminów zrozumiałych przez dzieci. „Mowa” słowa Bożego musi odpowiadać możliwościom percepcyjnym dziecka. Nie posługujemy się abstrakcyjnymi terminami, staramy się korzystać z konkretnych, obrazowych określeń, które przybliżają nam Boże pouczenia oraz pomagają w zrozumieniu ich. Nie należy stosować zdrobnień religijnych (np. Bozia, Pan Jezusek, Mateczka Najświętsza) ani zdrobnień wziętych z życia dziecka (rączka, buzia, nóżka, paluszek itp.). Dziecko winno spotykać się z takimi terminami, jakie nie będą towarzyły mu w dalszym życiu. Stąd poprawne będzie mówienie: Pan Bóg, Pan Jezus, Matka Boża, palec, ręka, twarz, noga itp. Unikamy także określeń z dawnego katechizmu czy też z tzw. ,żargonu kaznodziejskiego", które wprawdzie swoje korzenie mają w świecie Biblii i zawierają głębię oraz bogactwo treściowe, jednak w przypadku wykorzystania ich w odniesieniu do dziecka w niektórych wypadkach utrudniają mu zrozumienie problemu. Najczęstszym takim terminem jest "serce”. Mówi się o „czystym, brudnym, grzesznym, świętym sercu”. Według powyższego myślenia: Pana Jezusa przyjmujemy do serca, „oczyszczamy serce" w sakramencie pokuty. Dzieci konkretyzują takie określenia, rozumiejąc przez termin „serce” pracowity mięsień w organizmie człowieka. Niektóre mają trudności ze zrozumieniem, dlaczego przyjęty ustami Eucharystyczny Jezus przychodzi tylko do serca. To prawda, że nie jest łatwo nadprzyrodzoną rzeczywistość opisać słowami. Jednakże musimy uczyć się korzystania z takich określeń, które nie stwarzają dziecku trudności. Wydaje się, że można powiedzieć, iż „w Komunii świętej przyjmujemy Pana Jezusa" - nie określając, w której części organizmu się zatrzymuje. 
Drugim trudnym terminem jest „łaska”. Czy nie będzie bliższe dziecku określenie: „dar, prezent Boga, pomoc Boga”? Posługa słowa domaga się poprawnego odkrywania takich terminów, które bezbłędnie przybliżą dziecku nadprzyrodzoną rzeczywistość.

W przekazie posługujemy się prostymi zdaniami, o ile możliwe w czasie teraźniejszym, w trybie oznajmującym. Kierując pytania do dzieci, stosujemy szyk przestawny. Nie ujmujemy dwóch pytań w jednym zdaniu, np. „Gdzie i kiedy rodzi się Pan Jezus?”. Nie stosujemy podchwytliwych pytań, niezgodnych z obiektywną prawdą, typu: „Ilu jest Bogów?”. Rozpoczynając zdanie z formie oznajmującej, nie nakazujemy dziecku kończyć tego zdania, np. „Dwunastoletni Pan Jezus idzie w pielgrzymce do...”. Nie popełniamy też błędu określanego jako tzw. „pogłos pedagogiczny", który polega na dosłownym powtarzaniu przez katechetę wypowiedzi dziecka.

Chcąc otrzymać odpowiedź, stawiamy dziecku pytania poprawnie zbudowane. Jeśli chcemy otrzymać słowną odpowiedź - nie rozpoczynamy pytań od „czy”. Natomiast gdy zaczynamy pytanie od "czy”, wtedy nie wymagamy od dzieci osobistego zaangażowania, szukania własnej odpowiedzi na podstawie posiadanej wiedzy. W powyższym przypadku dzieci pokierują się intonacją naszego głosu, mimiką twarzy, by intuicyjnie wyczuć, na jaką czekamy odpowiedź, i skwitować ją bezmyślnym „tak” lub „nie”. Można zaczynać pytania od „„zy” przy pierwszych kontaktach z małymi dziećmi, by zachęcić je do głośnej odpowiedzi i ośmielić je przed księdzem. Gdy grupa zżyje się z prowadzącym, rozpoczynamy pytania od partykuły zmuszającej do twórczego komunikowania odpowiedzi na bazie posiadanego zakresu wiedzy, np. dlaczego?, w jaki sposób?, kiedy?, co robi? Pytaniem rozpoczętym od „czy” możemy się posłużyć przy refleksji, rachunku sumienia, podczas których 
dzieci udzielają odpowiedzi w myślach Bogu lub sobie. Jednak i wtedy warto zastanowić się także nad pytaniami od: w jaki sposób?, co zrobię?, co mogę zmienić?²

\section{Język homilii}

Mali uczestnicy liturgii więcej czasu spędzają przed telewizorem czy komputerem niż w kontaktach z opiekunami, a nawet rodzicami. Podświadomie oddziałuje na dzieci język mediów, który prostymi i krótkimi zdaniami podaje wszystkie wiadomości w sposób konkretny oraz zwięzły. W mentalności dziecka nie jest znane abstrakcyjne myślenie, trudne są też do przyjęcia teologiczne terminy, jak np. „plan Boży”, ,ekonomia zbawienia” kojarzone przez młodego odbiorcę z czysto ekonomicznymi, materialnymi działaniami, bez wiązania ich z religijnym sensem. Zachodzi także desakralizacja języka ukazująca utratę pierwotnego sensu religijnych terminów, jak np. „niebo” - kojarzone z chmurami czy też pogodą, oraz „odpust” - z wesołą zabawą ${ }^{3}$.

Dzięki językowi zdobywamy wiedzę, poszerzając znajomość nowych terminów, wyrażeń, pojęć, oraz nawiązujemy relacje międzyludzkie, a także między nami a Bogiem. Otwartą sprawą jest poszukiwanie nowych zasad używania języka nie tylko z członkami rodziny, przedszkola, szkoły, ale także w Kościele. Poprawny język homilii skutecznie wpływa na religijną formację człowieka. Język religijny posiada wyjątkową złożoność oraz spełnia bogate funkcje. Należą do nich funkcje: poznawcza, impresywna, ekspresywna oraz performatywna. Źródłami funkcji poznawczej są: Pismo Święte, Tradycja, Liturgia - jako

\footnotetext{
2 A. Długosz, Jak przygotować i oceniać katechezę, Częstochowa 1997, s. 63-66.

3 http://www.kongres.org/1zjazdsabadasz.htm, 29.07.2009.
} 
źródła formalne, oraz rzeczy stworzone - źródła materialne. W funkcji impresywnej nakłania się ludzi do religijnej aktywności, z kolei w ekspresywnej do czci wobec Boga poprzez pochwalną modlitwę oraz modlitwę wdzięczności. Funkcja performatywna służy tworzeniu rzeczywistości szczególnie podczas przeistoczenia. Powyższe funkcje języka mogą występować razem, co ma miejsce w liturgii, szczególnie podczas Eucharystii. Często mówi się nie tyle o języku religijnym, ile o sytuacji religijnej, w której używa się określonych rodzajów języka. Wskazuje się też na cztery typy języka: homilii, biblijnego, liturgicznego, egzystencjalnego i doktrynalnego. W języku biblijnym wyróżnia się język symboliczny wyrażony w metaforach, przypowieściach, parabolach, w języku sapiencjalnym, poetyckim, epistolarnym, w języku narracji czy analogii. Z kolei język liturgiczny obejmuje także język sakramentalny. Język liturgicznosakramentalny obejmuje: ryty, gesty, symbole, słowa, śpiewy, słuchanie. Język doktrynalny występuje w nauczaniu Kościoła ${ }^{4}$.

\section{Język Pisma Świętego skierowany do dzieci}

Interpretując historię zbawienia, stosujemy trójczłonowość przekazu - ponieważ tak powstawało Pismo Święte: doświadczenie życiowe narodu wybranego, na które Bóg odpowiada przez natchnionego autora, by z kolei zaprosić człowieka do dania odpowiedzi na propozycję Bożą.

Pismo Święte jest księgą zadaną człowiekowi, by ciągle odczytywał zbawcze przesłanie Pana Boga. Jako księga bosko-ludzka domaga się ona szczególnego przygotowania, które pozwoli

\footnotetext{
$4 \quad$ K. Misiaszek, Próba poszukiwania zasad używania języka w katechezie, http:// www.opoka.org.pl/biblioteka/T/TA/TAK/km_jezykzasady.html, 31.07.20o9.
} 
ją dobrze interpretowaćs. Spełnimy powyższe założenie, jeżeli dochowamy wierności Bogu i człowiekowi. W przybliżeniu prawdy Bożej wychodzimy od sytuacji znanej dziecku z codziennego życia. Następnie opowiadamy przekaz biblijny, by z kolei ukazać jeden ze sposobów realizacji Bożego wezwania. Koniecznie należy uwzględnić gatunki literackie występujące w Piśmie Świętym, na przykład pradzieje biblijne - nie są ścisłą historią, lecz stanowią obrazową odpowiedź na pytania ludzi: Skąd się wziął świat, człowiek? Jakie są relacje Boga do ludzi? Dlaczego cierpimy, umieramy, dlaczego występują podziały między ludźmi?

Ewangeliczny język adresowany do dzieci jest ściśle związany z życiem Kościoła, a w nim z przepowiadaniem biblijnym i posługą liturgiczną, z tradycją i nauczaniem Kościoła oraz z doświadczeniem codziennego życia. Ma to być język działania, gestów, śpiewu, tańca, obrazu, opisu, porównań, poszukiwań, medytacji.

Ważne jest wytłumaczenie symboliki biblijnej oraz topografii Palestyny. Wszystkie wydarzenia tak ze Starego, jak i z Nowego Testamentu przepowiadamy w czasie teraźniejszym, by dziecko, słuchając danego fragmentu Biblii, było aktorem czynnym, a nie tylko wspominającym zbawcze wydarzenia. Historia zbawienia dokonuje się aktualnie na kanwie naszego życia. Podejmujemy zadania bohaterów biblijnych, by współuczestniczyć w zbawczej działalności Pana Boga. Imię Boga „Ja Jestem" przypomina o obecności Boga w życiu każdego człowieka. Dzięki temu mali odbiorcy Bożego słowa zaangażują się w realizację propozycji, jaką Bóg kieruje do nich?7.

\footnotetext{
5 A. Długosz, Chrześcijanin radosny, Kraków 2008.

6 A. Długosz, Dobry Bóg mówi do nas, Częstochowa 2009; A. Długosz, Opowiem ci o Jezusie, Kraków 2008.

7 A. Długosz, Katechetyczne przestanie znaków Starego Testamentu, Kraków 1994, s. 31n.
} 


\section{Pomoce audiowizualne w homilii}

Przygotowując homilię, staramy się wielopłaszczyznowo oddziaływać na dzieci. Chodzi nam o zaangażowanie zmysłów: wzroku, słuchu, powonienia, dotyku, smaku. Do pomocy wizualnych zaliczamy wszystkie, które są możliwe do oglądania: obrazy ${ }^{8}$, flanelogramy, przeźrocza, rekwizyty, modele, wideokasety, filmy ${ }^{9}$. Dzielimy je na religijne i świeckie. Religijne segregujemy według następujących działów: biblijne (Stary i Nowy Testament), liturgiczne (wyszczególniające tematykę poszczególnych sakramentów), obrzędowe (związane z okresowymi nabożeństwami czy świętami), historyczne (ukazujące wydarzenia z historii Kościoła, parafii, narodu).

Świeckie pomoce wizualne swoją tematyką będą poruszały epizody wzięte z życia: domowego, szkolnego, rówieśniczego, kulturalnego (gdzie uwzględnimy działy: film, teatr, muzyka, sport itd.), społecznego (nauka, wojna, pokój itd.).

Podobne działy winny wystąpić przy dzieleniu rekwizytów, wśród których nie może zabraknąć paramentów liturgicznych, religijnych symboli i naczyń liturgicznych. Do pomocy słuchowych zaliczymy nagrania słuchowisk, audycji, wypowiedzi i wywiadów. Materiał słuchowy stanowią wszelkie nagrania dźwiękowe. Podręczną pomocą są dobre podkłady muzyczne, nagrania pieśni, piosenek religijnych oraz świeckich itd. W tym dziale możemy zachować podobny podział pomocy, jak w przypadku dodatków wizualnych. Każda pomoc winna być nośnikiem treści lub jej przypomnieniem. Dobrze przemyślana i zastosowana w homilii może zainteresować odbiorcę i go

8 S. Kulpaczyński, Formy obrazowe i metodyka ich zastosowania w katechezie, [w:] Katechizacja różnymi metodami, red. M. Majewski, Kraków 1994, s. 185-20o.

9 S. Kulpaczyński, Katecheza przy pomocy środków audiowizualnych, [w:] Katechizacja różnymi metodami, dz. cyt., s. 201-220; R. Podpora, Wideokaseta w katechezie, [w:] Katechizacja różnymi metodami, dz. cyt., s. 221-227. 
ożywić. Pomoce słuchowe powinny prezentować dobrą jakość tak pod względem muzycznym, jak i w podawanym tekście.

Wizualne pomoce powinny być "czytelne”, to znaczy nie mogą stwarzać poważnych trudności w odebraniu przez dzieci niesionej przez nie treści. Oceniamy je także w kontekście możliwości percepcyjnych dzieci. W przypadku młodszych odbiorców wizualna pomoc nie może zawierać dużej liczby drugorzędnych szczegółów, gdyż będzie wtedy rozpraszała dzieci czy też kierowała ich zainteresowanie na niewłaściwy obiekt znajdujący się na pokazywanym materiale. Ważną rolę odgrywa kolor. Dobrze będzie posługiwać się kolorowymi pomocami.

Wizualne pomoce nie mogą materializować świata duchowego: przedstawiać Pana Boga, Ducha Świętego, aniołów czy diabłów. Błędem będzie, jeżeli posłużymy się pomocami wizualnymi prezentującymi dzieła sztuki sakralnej ukazującej świat duchów. Wprawdzie Pismo Święte w niektórych sytuacjach "materializuje” osoby duchowe, ale trzeba dobrze odczytać kontekst takiego przekazu i jego gatunek literacki. Dzieci od początku formacji liturgicznej muszą doświadczać tajemnicy. Informujemy je, że nikt z ludzi nie widział Pana Boga, Ducha Świętego, aniołów, diabłów, dlatego nie możemy ich pokazywać na obrazach ani rysować. Tę prawdę dzieci przyjmą, bazując na autorytecie głosiciela homilii. Wprawdzie podzielą się wiedzą, że w niektórych kościołach widziały namalowane osoby duchowe, lecz wtedy wyjaśniamy im, że obrazy te są oparte na wyobraźni artysty malarza, ale nie stanowią prawdy dotyczącej wyglądu Boga czy anioła. Nie możemy pogłębiać wśród dzieci antropomorfizacji Boga - takiej cechy dziecięcej, z której dziecko powoli powinno wychodzić. Dzieci przyjmą, że duchy nie mają ciała, dlatego nie możemy ich zobaczyć. 
Pierwszy kontakt z Panem Jezusem powinien wystąpić przez obraz ukazujący Chrystusa jako dorosłego człowieka, ponieważ dziecko ma zapotrzebowanie na silnego Boga. Oczywiście w okresie Bożego Narodzenia dzieci dowiedzą się, że ten silny i dorosły Pan Jezus ma matkę, która nosi Go przez dziewięć miesięcy w sobie, a następnie rodzi w Betlejem. Z tej okazji pokazujemy Jezusa jako dziecko leżące w żłobie czy figurę małego Jezusa. Jednak pierwsze doświadczenie Boga związane jest z dorosłym Jezusem.

Pokazujemy wszystkie postacie biblijnego świata, z historii ludzkości i współczesne. Nie posługujemy się obrazami o tematyce baśniowej, bajkowej, legendarnej, apokryficznej. Obrazy, przeźrocza winny mieć odpowiednią wielkość, by obecni na mszy świętej mogli z nich korzystać.

Pokazując obraz, nie stawiamy pytań dotyczących jego tematyki. Pozwalamy najpierw dobrze mu się przyjrzeć. Bodźce wzrokowe u dzieci są silniejsze od słuchowych, stąd mogą one nie słyszeć naszego pytania, gdy jednocześnie z pokazaniem obrazu coś mówimy. Dzieci nie są w stanie podzielić uwagi na równoczesne „oglądanie” $\mathrm{i}$,słuchanie”.

Młodsze dzieci ukierunkowujemy przy pomocy pytań: Kto jest na obrazie? Kogo widzimy? Co robi ta osoba? Jak jest ubrana? Starszym dzieciom pozwalamy na odczytanie od razu ogólnej treści.

Pomoce wizualne wykorzystujemy w podwójny sposób: po pierwsze przy przekazie nowego materiału, czyli w przypadku, gdy są one nośnikami czegoś nieznanego i służą ubogaceniu, poszerzeniu wiadomości; po drugie przy powtórzeniu lub przypomnieniu już znanych treści. 


\section{Zakończenie}

Na historię naszego życia składają się spotkania z ludźmi, wykonywane prace, szeroki wachlarz innych działań, słowne przesłania ubogacające czy sprawiające ludziom ból. Szczególną rolę i wpływ w historii naszego życia obok spotkań z ludźmi mają doświadczenia spotkań z Chrystusem. Przygodę wspólnoty i przyjaźni z Nim rozpoczynamy w sakramencie chrztu, by dia$\log$ z Bogiem i Jego zbawcze ingerencje nieprzerwanie trwały przez całe życie. W podtrzymywaniu rozmowy z Bogiem i poznawaniu głębi Jego zbawczych działań pomagają homileci - Jezusowi prorocy. Wprawdzie profetyczne powołanie otrzymują w darze od Chrystusa, jednak za przygotowanie do prorockiej misji oraz za jej skuteczną posługę sami ponoszą odpowiedzialność. 